\title{
EVALUASI KEPUASAN MAHASISWA DALAM PROBLEM BASED LEARNING ASUHAN KEBIDANAN KEHAMILAN DI PROGRAM STUDI KEBIDANAN PADANGSIDIMPUAN
}

\author{
Irwan Batubara, Djaswadi Dasuki, Mubasysyir Hasanbasri \\ Prodi Kebidanan Padang Sidimpuan Poltekkes Kemenkes Medan
}

\begin{abstract}
Abstrak
Lulusan pendidikan bidan yang ditempatkan di fasilitas kesehatan dan desa belum memberikan konstribusi efektif terahadap percepatan penurunan angka kematian ibu dan angka kematian bayi. Pendidikan D III kebidanan dengan kurikulum berbasis kompetensi berupaya melakukan perubahan sistem pembelajaran konvensional menuju pembelajaran berbasis masalah (problem-based learning). Salah satu ciri problembased learning $(P B L)$ self-directed learning, diintegrasikan dalam diskusi kelompok, diaplikasikan di laboratorium dan praktek klinik pada objek nyata mewujudkan sikap profesi bidan mandiri yang mampu memberi pelayanan dalam siklus kehidupan wanita berdasarkan bukti. Untuk mengetahui hubungan kegiatan pembelajaran yang diterapkan dosen/tutor di kelas, laboratorium, praktek klinik dan kelengkapan alat-bahan pembelajaran dengan kepuasan mahasiswa dalam asuhan kebidanan diagnosa kehamilan di Program Studi Kebidanan Padangsidimpuan. Penelitian ini menggunakan metode kuantitatif dan kualitatif dengan pendekatan cross-sectional study. Populasi mahasiswa tingkat II reguler Program Studi Kebidanan Padangsidimpuan berjumlah 50 orang ditambah 3 orang fasilitator, seluruhnya dijadikan subjek penelitian (purposive sampling). Analisis data menggunakan chi-square, regresi logistik dengan pemodelan dan analisa kualitatif. Hubungan kegiatan pembelajaran yang diterapkan dosen/tutor dengan kepuasan mahasiswa dalam pembelajaran asuhan kebidanan diagnosa kehamilan bermakna dengan nilai $p=0,0001$; RP sebesar 9,5 $(\mathrm{CI} 95 \%=3,75-24.01)$ menjelaskan kegiatan pembelajaran memiliki risiko 9,5 kali mempengaruhi kepuasan mahasiswa dalam pembelajaran asuhan kebidanan diagnosa kehamilan. Kegiatan pembelajaran sesuai kriteria seven jump signifikan meningkan kepuasan mahasiswa dalam pembelajaran asuhan kebidanan diagnosa kehamilan.
\end{abstract}

Kata kunci : Kegiatan pembelajaran, kepuasan mahasiswa

\section{PENDAHULUAN}

Bidan salah satu tenaga kesehatan yang memiliki posisi penting dan strategis terutama dalam penurunan angka kematian ibu dan kematian bayi. Bidan memberikan pelayanan kebidanan yang berkesinambungan dan paripurna, fokus pada upaya pencegahan, promosi dengan pemberdayaan masyarakat, kemitraan bersama-sama dengan tenaga kesehatan lainnya untuk senantiasa siap melayanai siapa saja yang membutuhkan dimanapun berada ${ }^{1}$. Pendidikan kebidanan harus mengedepankan kualitas lulusan berbasis kemandirian pada praktek, mengembangkan kreativitas kinerja yang dapat dibuktikan dengan budaya kompetensi dan terampil dalam perawatan siklus kehidupan wanita ${ }^{2}$. Pendidikan kebidanan perlu mensikapi perubahan metode pembelajaran yang diterapkan inovasi berbasis masalah, fokus pada mahasiswa intensif pada sumber belajar dengan bimbingan tutor sebagai fasilitator. Ciri problem-based learning (PBL) self-directed learning, diintegrasikan dalam diskusi kelompok, diaplikasikan di laboratorium dan praktek klinik pada objek nyata mewujudkan sikap profesi bidan mandiri yang mampu memberi pelayanan dalam siklus kehidupan wanita berdasarkan bukti ${ }^{3}$.

Program Studi Kebidanan Padangsidimpuan dalam proses pembelajaran berpedoman pada kurikulum pendidikan bidan (2000) berbasis kompetensi, metode pembelajaran diskusi kelompok, tanya jawab, presentase, penugasan terstruktur dan ceramah $^{4}$. Pembelajaran dilaksanakan di kelas, laboratorium, praktek klinik rumah sakit, puskesmas dan masyarakat. Mhasiswa semester III-VI diterapkan sistem blok (2008), satu bulan pembelajaran kelas, laboratorium dan bulan berikutnya praktek klinik di fasilitas kesehatan yang aktif memberikan pelayanan KIA. Berdasarkan kegiatan pembelajaran yang diterapkan dosen/tutor ciri pembelajaran berbasis masalah, peneliti ingin mengetahui metode pemebelajaran berbasis lengkap atau belum untuk perbaikan dimasa yang akan datang, jika metode ini mendapat respon positif dari mahasiswa untuk mencapai tujuan pembelajaran. Penelitian ini fokus pada evaluasi kepuasan mahasiswa dalam kegiatan pembelajaran yang diterapkan dosen/tutor di kelas, 
laboratorium, praktek klinik dan sumber belajar asuhan kebidanan kehamilan di Politeknik Kesehatan Kementerian Kesehatan Medan Program Studi Kebidanan Padangsidimpuan.

\section{METODE PENELITIAN}

Jenis penelitian kuantitatif dan kualitatif, dengan pendekatan cross-sectional study, bertujuan untuk memperoleh gambaran kegiatan pembelajaran yang diterapkan dosen/tutor dengan kepuasan mahasiswa dalam asuhan kebidanan kehamilan. Populasi, mahasiswa tingkat II Program Studi Kebidanan Padangsidimpuan berjumlah 50 orang di tambah fasilitator 3 orang. Sampel dalam penelitian purposive sampling.

Variabel independen dalam penelitian ini terdiri dari kegiatan pembelajaran dikelas, laboratorium, praktek klinik di rumah sakit dan sumber belajar. Variabel dependen kepuasan mahasiswa dalam pembelajaran asuhan kebidanan kehamilan. Variabel luar yang mempengaruhi pembelajaran dan kepuasaan mahasiswa adalah pendidikan mahasiswa sebelumnya dan peran dosen/tutor dalam pembelajaran asuhan kebidanan kehamilan. Analisis data univariabel, bivariabel, multivariabel dengan menggunakan uji statistik chi-square dan logistic regression dengan tingkat confidence interval (CI95\%).

\section{HASIL PENELITIAN}

Uji statistik yang digunakan adalah chi-square dengan nilai $p<0.05$ menunjukkan hubungan yang bermakna secara statistik. Nilai RP (risiko relatif) sama dengan 1 diartikan sebagai variabel yang diduga sebagai faktor risiko yang tidak berpengaruh terhadap kepuasan mahasiswa dalam pembelajaran asuhan kebidanan kehamilan. Nilai RP kurang dari 1 (CI 95\% tidak mencakup angka 1) maka faktor risiko bersifat protektif dan selanjutnya bila nilai $\mathrm{RP} \geq 1$ maka variabel tersebut merupakan faktor risiko yang dianggap mempengaruhi rendahnya kepuasan mahasiswa dalam pembelajaran asuhan kebidanan diagnosa kehamilan.

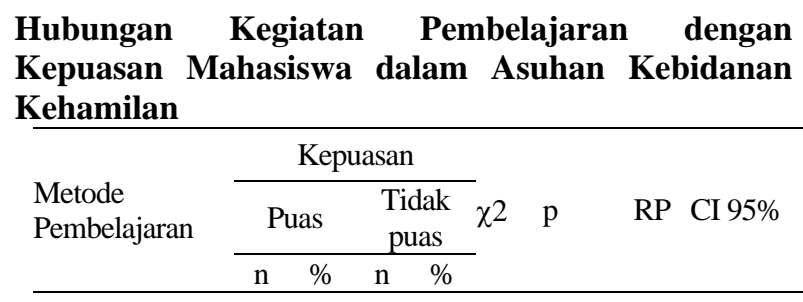

PBL

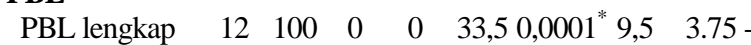

$\begin{array}{llllll}\text { PBL tidak } & 4 & 10,5 & 34 & 89,5 & 24.01\end{array}$ lengkap

\begin{tabular}{ll}
\hline Keterangan : & \\
$\mathrm{n}=$ Jumlah mahasiswa & $p=p$ Value \\
$x^{2}=$ Chi-Square & $\mathrm{RP}=$ Rasio Prevalensi \\
CI95\% = Confidence & Interval $*$ Signifikansi $(p<0.05)$ \\
$95 \%$ &
\end{tabular}

Terdapat hubungan yang bermakna antara kegiatan pembelajaran dengan kepuasan mahasiswa dalam pembelajaran asuhan kebidanan kehamilan dengan nilai $\mathrm{p}=0,0001$. Nilai $\mathrm{RP}$ sebesar 9,5 $(\mathrm{CI} 95 \%=3,75-24.01)$ menjelaskan kegiatan pembelajaran yang diterapkan dosen/tutor memiliki risiko 9,5 kali untuk mempengaruhi ketidak kepuasan mahasiswa dalam pembelajaran asuhan kebidanan kehamilan.

Hasil Analisis Chi square Kegiatan Pembelajaran dengan Kepuasan Mahasiswa dalam Asuhan Kebidanan Kehamilan

\begin{tabular}{|c|c|c|c|c|c|c|c|c|}
\hline \multirow{3}{*}{ Pembelajaran } & \multicolumn{4}{|c|}{ Kepuasan } & \multirow{3}{*}{$\chi^{2}$} & \multirow{3}{*}{$\mathrm{p}$} & \multirow{3}{*}{$\mathrm{RP}$} & \multirow{3}{*}{ CI $95 \%$} \\
\hline & \multicolumn{2}{|c|}{ Puas } & \multicolumn{2}{|c|}{ Tidak puas } & & & & \\
\hline & $\mathrm{n}$ & $\%$ & $\mathrm{n}$ & $\%$ & & & & \\
\hline \multicolumn{9}{|l|}{ Pembelajaran kelas } \\
\hline - Lengkap & 14 & 60,9 & 9 & 39,1 & & & & \\
\hline - $\quad$ Tidak lengkap & 2 & 7,4 & 25 & 92,6 & 16,3 & 0,0001 & 8,2 & $2,1-32,4$ \\
\hline \multicolumn{9}{|l|}{ Pembelajaran labor } \\
\hline - $\quad$ Lengkap & 21 & 56,7 & 16 & 43,2 & 8,2 & & & \\
\hline - $\quad$ Tidak lengkap & 13 & 100 & 0 & & & 0,0002 & & \\
\hline Pembelajaran klinik & & & & & & & 24,5 & \\
\hline - Lengkap & 15 & 78,9 & 4 & 21,1 & 31,1 & & & \\
\hline - $\quad$ Tidak lengkap & 1 & 3,2 & 30 & 96,8 & & 0,0026 & & $3,5-170.6$ \\
\hline \multicolumn{9}{|l|}{ Kelengkapan alat } \\
\hline - Lengkap & 15 & 57.7 & 11 & 42,3 & 16,4 & & 13,8 & \\
\hline - $\quad$ Tidak lengkap & 1 & 4,2 & 23 & 95,8 & & & & $1,8-97,0$ \\
\hline \multicolumn{9}{|l|}{ Pendidikan mahasiswa } \\
\hline - SMA & 12 & 24,6 & 26 & 64,5 & 0,13 & 0,0001 & 0,95 & \\
\hline - SMK & 4 & 33,3 & 8 & 66,7 & & 0,586 & & $0,37-2,39$ \\
\hline \multicolumn{9}{|l|}{ Peran dosen } \\
\hline - $\quad$ Baik & 16 & 35,5 & 29 & 64,5 & 2,64 & 0,13 & & \\
\hline - $\quad$ Kurang baik & 0 & 0 & 5 & 100 & & & & \\
\hline
\end{tabular}

Keterangan:

$\mathrm{n}=$ Jumlah responden

$x^{2}=$ Chi-Square

$p=p$ Value

CI95\% = Confidence Interval 95\%

$\mathrm{RP}=$ Rasio Prevalensi 
Analisis multivariabel

Hasil Analisis Regresi Logistik hubungan Kegiatan Pembelajarandengan Kepuasan Mahasiswa dalam Asuhan Kebidanan Kehamilan

\begin{tabular}{|c|c|c|c|c|}
\hline \multirow{3}{*}{ Pembelajaran } & Model 1 & Model 2 & Model 3 & Model 4 \\
\hline & $\mathrm{RP}$ & $\mathrm{RP}$ & $\mathrm{RP}$ & $\mathrm{RP}$ \\
\hline & (CI 95\%) & (CI 95\%) & (CI 95\%) & (CI 95\%) \\
\hline \multicolumn{5}{|l|}{ Pembelajaran kelas } \\
\hline - Lengkap & 5,41 & & 6,01 & 3,15 \\
\hline - Tidak Lengkap & $(1,47-19,90)^{*}$ & & $(1,59-22,60)^{*}$ & $(0,99-10,05)$ \\
\hline \multicolumn{5}{|c|}{ Sumber pembelajaran } \\
\hline - Lengkap & 9,32 & 3,69 & & 2,09 \\
\hline - Tidak Lengkap & $(1,39-62,33)^{*}$ & $(0,60-22,54)$ & & $(0,49-8,27)$ \\
\hline \multicolumn{5}{|l|}{ Pembelajaran klinik } \\
\hline - Lengkap & & 13,53 & 3,29 & 11.81 \\
\hline - Tidak Lengkap & & $(1,82-100,29)^{*}$ & $(1,38-7,91)^{*}$ & $(1,56-89,01)^{*}$ \\
\hline $\mathrm{N}$ & 50 & 50 & 50 & 50 \\
\hline $\mathrm{R}^{2}$ & 0,30 & 0,36 & 0,26 & 0,40 \\
\hline Deviance & 28,91 & 23,43 & 33,47 & 14,42 \\
\hline
\end{tabular}

Keterangan:

$\mathrm{N}=$ Jumlah responden

$\mathrm{RP}=$ Rasio Prevalensi

$\mathrm{R}^{2}=$ Koefisien determinasi

$$
\begin{aligned}
& \mathrm{CI}=\text { Confident Interval } \\
& \quad *=\text { bermakna/signifikan }
\end{aligned}
$$

Model 1 untuk mengetahui hubungan kegiatan pembelajaran di kelas dan kelengkapan sumber belajar dengan kepuasan mahasiswa dalam pembelajaran asuhan kebidanan kehamilan tanpa mengikut sertakan variabel lain. Hasil analisis menunjukkan RP 5,41; CI $95 \%=1,47-19,90$. Nila $\mathrm{R}^{2,}$ model 1 dapat memprediksi kepuasan mahasiswa dalam pembelajaran asuhan kebidanan kehamilan 30\%. Model 2 melihat hubungan sumber pembelajaran dan praktek klinik dengan kepuasan mahasiswa dalam pembelajaran asuhan kebidanan kehamilan. Hasil analisis membuktikan nilai $\mathrm{R}^{2,}$ mengalami peningkatan kepuasan mahasiswa $36 \%$ dan tidak mempunyai hubungan yang bermakna dengan nilai $\mathrm{RP}=3,69$; CI 95\% $=0,60-22,54$. Kepuasan mahasiswa memiliki proporsi 3,69 kali lebih puas dalam pembelajaran asuhan kebidanan. Model 3 melihat hubungan kegiatan pembelajaran di kelas dan praktek klinik dengan kepuasan mahasiswa dalam pembelajaran asuhan kebidanan kehamilan. Hasil analisis mempunyai hubungan yang bermakna dengan nilai $\mathrm{RP}=6,01$; CI $95 \%=1,59-22,60$. Kepuasan mahasiswa memiliki proporsi 6,01 kali lebih puas dalam pembelajaran asuhan kebidanan. Model 4 melihat hubungan kegiatan pembelajaran di kelas, praktek klinik, dan sumber pembelajaran dengan kepuasan mahasiswa dalam asuhan kebidanan kehamilan. Hasil analisis membuktikan nila $\mathrm{R}^{2 \text {, }}$ mengalami peningkatan kepuasan mahasiswa 40\%, dan mempunyai hubungan bermakna dengan nilai RP 11,81; CI $95 \%=1,56-89,01$. Artinya kepuasan mahasiswa memiliki proporsi 11,81 kali lebih puas dalam pembelajaran. Berdasarkan analisis pemodelan, peneliti cenderung untuk memilih model 4 , atas dasar pertimbangan logis, statistik dan praktis lebih efektif meningkatkan kepuasan mahasiswa dalam pembelajaran asuhan kebidanan kehamilan. Pembelajaran berbasis masalah (PBL) efektif dilaksanakan pada pembelajaran praktek klinik.

Hubungan kegiatan pembelajaran dengan kepuasan mahasiswa dalam asuhan kebidanan diagnosa kehamilan.

Hasil penelitian tabel 1 menunjukkan rerata ketidakpuasan mahasiswa $68 \%$ dalam pembelajaran yang diterapkan dosen/tutor di kelas, laboratorium dan praktek klinik. Secara deskriptif membuktikan kurangnya pengetahuan dan keterampilan yang dimiliki oleh dosen/tutor dalam manajemen pengelolaan kelas dan pemanfaatan sumber pembelajaran untuk memotivasi mahasiswa intensif pada sumber belajar. Bukti statistik pada Tabel 4 terdapat hubungan yang bermakna antara kegiatan pembelajaran dengan kepuasan mahasiswa dalam asuhan kebidanan kehamilan, nilai $p=0,0001$; RP sebesar 9,5; CI 95\%= 3,75-24,01. Hal ini menjelaskan kegiatan pembelajaran yang diterapkan dosen/tutor memiliki risiko 9,5 kali mempengaruhi ketidakpuasan mahasiswa dalam pembelajaran asuhan kebidanan kehamilan. Kegiatan pembelajaran yang diterapkan/dosen mayoritas PBL tidak lengkap $38(76 \%)$ dan mahasiswa tidak puas. Nilai $\mathrm{X}^{2}=$ 33,5 artinya nilai peubah kegiatan pembelajaran yang diterapkan dosen (observasi) tidak sesuai dengan harapan mahasiswa, semakin kecil nilai $\mathrm{X}^{2}$ observasi dengan harapan semakin baik mewujudkan tujuan pembelajaran (mahasiswa puas). 
Problem based learning dilaksanakan lengkap mahsiswa merasa puas signifikan dengan hasil penelitian; Kepuasan mahasiswa lebih baik pada sesi PBL dibandingkan dengan duduk dalam kuliah karena dapat medorong aktivasi dan elaborasi pengetahuan sebelumnya dan memungkinkan proses pengembangan kognitif ${ }^{1,5}$. Pendidik pada dasarnya harus menyadari standar kurikulum yang dibutuhkan, kompetensi inti dari bidang studi, kemudian menyusun rencana pembelajaran dengan pertimbangan kecukupan waktu, mahasiswa, metode dan sumber daya. Proses pembelajaran akan berlangsung efektif jika mahasiswa terlibat secara aktif dalam tugastugas yang bermakna, dan berinteraksi dengan materi pembelajaran secara intensif. Penugasan belajar mandiri meningkatkan kemampuan mengaplikasikan pengetahuan dalam aktivitas nyata, dan intraksi yang berkesinambungan sesama teman sejawat memungkinkan mahasiswa untuk melakukan konfirmasi terhadap pengetahuan dan keterampilan pembelajaran ${ }^{6,7}$. Probem-based learning inovasi dalam metode pembelajaran, dosen/tutor sebagai fasilitator kreatif mengembangkan kemampuan dan keahlian yang berhubungan dengan bidang tugasnya. Kualitas dan atribut fasilitator memberikan dampak yang signifikan pada proses pembelajaran, agar belajar terasa nyaman dan tercipta diskusi yang terbuka dibutuhkan fasilitator kreatif, terbuka, fleksibel, berpikir positif, inovatif dan penuh motivasi dalam kelompok diskusi $^{2,8}$.Tantangan pembelajaran di Program Studi Kebidanan Padangsidimpuan; kurangnya jumlah fasilitator jika dibandingkan dengan kelompok mahasiswa, kualifikasi pengetahuan belum memadai sehingga mahasiswa tidak terfasilitasi optimal dalam pembelajaran. Fasilitator berupaya meningkatkan kemampuan melalui pendidikan formal dan pelatihan yang relevan dengan tugasnya, kemampuan teknologi dan psikologi pendidikan untuk mendisain kegiatan pembalajaran berbasis masalah yang efektif dan efisien.

Problem based learning efektif dilaksanakan dalam pembelajaran praktek klinik, hal ini sependapat dengan hasil penelitian Aari, PBL lebih efektif meningkatkan keterampilan mahasiswa pada pembelajaran klinik dibandingkan dengan metode konvensional $^{1,9}$. Pembelajaran klinik peluang bagi mahasiswa untuk memperoleh norma, prilaku bidan sebagai bagian dari komunitas praktek, sosialisasi profesional sebagai proses belajar budaya profesi, kemampuan, nilai, sikap dan keterampilan yang membuat mahasiswa semakin percaya diri. PBL memiliki kelebihan seperti menyediakan pengalaman belajar yang jauh lebih menyenangka, keterampilan profesional dan praktek ilmu dasar dilaksanakan dengan pendekatan berbasis kompetensi dan pembimbing mengambil peran pembinaan bekerja sampai mencapai tingkat kompetensi. Keputusan kelinik asuhan kebidanan kehamilan lebih akurat karena mereka lebih cendrung menggunakan konsepkonsep sains, mengembangkan kemampuan dalam pemecahan masalah secara akurat dan menerapkannya pada siatuasi masalah baru. Peranan tutor dalam praktek klinik adalah mengintegrasikan pembelajaran klinik efisien dengan tugas perawatan pasien, sehingga beban kerja tidak menimbulkan konflik dan saling mendapat perhatian. Peningkatan beban kerja tutor untuk satu orang mahasiswa dan satu pasien sekitar 45 menit setiap harinya 9 . Tutor belajar dari pengalaman kegagalan atau ketidak puasan untuk memodifikasi strategi metode pembelajaran efektif, seperti membuat jadwal harian, koordinasi dengan pendidikan untuk membatasi jumlah bimbingan, meningkatkan kinerja tim dan melibatkan staf dengan pengawasan dan bimbingan.

\section{Sumber pembelajaran dengan kepuasan mahasiswa dalam asuhan kebidanan kehamilan.}

Hasil penelitian membuktikan sumber belajar (alat-bahan) pembelajaran tidak lengkap 23 (46\%) mahasiswa tidak puas dan mahasiswa tidak puas walaupun alat lengkap $11(22 \%)$. Secara deskriptif alatbahan adalah sumber belajar, jika tidak lengkap atau jumlahnya kurang menghambat tansformasi materi pembelajaran dan membutuhkan waktu lebih lama dalam penyelesaian tugas. Secara statistik terdapat hubungan yang bermakna antara kepuasan mahasiswa dengan kelengkapan alat-bahan pembelajaran dan dapat meningkatkan kepuasan mahasiswa 13,8 kali jika ketersedian alat-bahan pembelajaran lengkap. Aktivitas pembelajaran mahasiswa berinteraksi dengan sumber belajar; mendemontrasikan, mempraktekkan, mensimulasikan, mengadakan eksprimen, menganalisis, mengaplikasikan, menemukan, mengamati, meneliti, efektivitas dan efisien proses dipengaruhi kelengkapan alat-bahan sebagai sumber belajar. menjelaskan hambatan dalam pembelajaran, kurangnya alat-bahan mahasiswa tidak dapat menyelesaikan pembelajaran kelompok tepat waktu dan tutor mengalami kesulitan mengoptimalkan bimbingan, harapan peningkatan pencapaian kompetensi pembelajaran fokus pada mahasiswa tidak tercapai ${ }^{10,16}$. Alat dan bahan adalah sub-komponen dalam simtem pembelajaran.

Sumber pembelajaran sesuai kebutuhan topik pembelajaran, mahasiswa diberi kesempatan mengerjakan langsung, dan menemukan sendiri materi pembelajaran dengan bimbingan dosen/tutor sebagai fasilitator mahasiswa mampu mandiri melaksanakan asuhan kebidanan tanpa tergantung sepenuhnya pada dokter ahli. Sumber pembelajaran asuhan kebidanan terdiri dari media pembelajaran (audiovisual), kebutuhan praktek laboratorium/klinik (pemeriksaan ibu hamil), sumber pustaka dan alat transpormasi informasi untuk mengintegrasikan dan membanding hasil pengumpulan data ibu hamil sehingga keputusan klinik atau diagnosa tepat berdasarkan bukti. Dosen/tutor merencanakan pembelajaran mempertimbangkan: 1) ketersediaan sumber belajar baik dari jumlah maupun kualitasnya, 2) ketersediaan dana, tenaga dan fasilitas, 3) keluesan, kepraktisan penggunaan sumber belajar, serta 4) efektifitas sumber belajar dengan waktu ${ }^{10}$. Fasilitator memiliki keterampilan menggunakan alat-bahan dalam 
pengumpulan data ibu hamil, mengusai konstektual menentukan diagnosa beradasarkan evidance base dan pemodelan jika memungkinkan menyerupai bentuk, fungsi aslinya ${ }^{10,17}$. Berbagai upaya yang dapat dilaksanakan untuk meminimalisir dampak kekurangan alat-bahan dalam pembelajaran:

1) distribusi merata pada setiap kelompok dan terjadwad, 2) pemodelan jika memungkinkan menyerupai bentuk aslinya, 3) penambahan waktu atas kesepakatan tutor dengan kelompok diluar jam terjadwa, dan memberdayakan lembaga atau institusi tempat praktek $^{10,18}$. Inventarisasi alat-bahan dilaksanakan setiap akhir semester untuk mengetahui kelengkapannya, kualitasnya, penataannya, dilaporkan ke Jurusan Kebidanan dilanjutkan ke Direktorat Politeknik Kesehatan Medan, pengadaannya oleh Poltekkes dan didistribusi kependidikan.

\section{DAFTAR PUSTAKA}

Aari RL, Elomaa L, Ylonen M, Saarikoski M. Problembased learning in clinical practice: employment and education as development partners. Nurse Educ Pract.2008; 8 (6): 420-427.

Ali GM, Sebai NAM. Effect of problem-based learning on nursing student approaches to learning and their self directed learning abilities. International Journal of Academic Research.2010; 2 (4): 188-195.

Botti J. PBL Scenario Essential. Published in the proceedings of the PBL International Conference, Cancun, Mexico, June 2004.

Departemen Kesehatan RI Kurikulum Pendidikan Diploma III Kebidan, Jakarta; 2004.

Gurpinar E, Alimoglu MK, Mamakli S, Aktekin M. Can learning style predict student satisfactin with different instruction methods and academic achievement in medical education?. Advances in Pshysikology Education.2010; 34 (4): 192-196
Dochy ., Seger, M, Bossc PVd, Gijbels D. Effects of problem-based learning: a metaanalysis. Learning and Instruction. 2003; 13: 533-568.

Hmelo-Silver CE. Problem-based learning: What and how do students learn? Educational Psychology Review. 2004; 16 (3): 235-266.

Wood DF. ABC of learning teaching in medicine: Problem based learning. BMJ.2003; 326.

Raisler J, O'Grady M, Lori J. Clinical teaching and learning in midwifery and women's health. J Midwifery Womens Health. 2003; 48 (6): 398-406.

Spinello E, Fischbach R. Problem-based learning in public health instruction: a pilot study of an online simulation as a problem-based learning approach. Educ Health (Abingdon). 2004; 17 (3): 365-373.

Kokom K. Pembelajaran Kontekstual Konsep dan Aplikasi. Rafika Aditama, Bandung ;2010.

Thomas GB. An evidance-based strategy for midwifery education. The Royal College of Midwives Based Midwifery. 2007; 5 (2): 47-53.

Gordon J. ABC of learning and teaching in medicine: one to one teaching and feedback. BMJ. 2003; 326 (7388): 543-5.

Morrison J. ABC of learning and teaching in medicine: Evaluation. BMJ. 2003; 326 (7385): 385-387.

Prideaux D. ABC of learning and teaching in medicine. Curriculum design. BMJ.2003; 326 (7383): 268270.

Savin-Baden, M. Problem-based Learning In Higher Education: Untold Stories, Philadelphia, PA: Open University Press; 2000.

Vahidi R, Azemian A, Zadeh S. Feasibility of PBL implementation in clinical courses of nursing and midwifery from the view points of faculty members of Tabriz University of Medical Sciences. Journal of Medical Education. 2004; 4 (2): 71-76.

Wood DF. ABC of learning teachin in medicine: Problem based learning. BMJ.2003; 326 